See discussions, stats, and author profiles for this publication at: https://www.researchgate.net/publication/313257011

Attitudes Toward Spanish and Code-Switching in Belize: Stigmatization and Innovation in the Spanish Classroom

Article in Journal of Language Identity \& Education · January 2017

DOI: 10.1080/15348458.2016.1260455

CITATIONS

7

2 authors:

Osmer Balam

College of Wooster

13 PUBLICATIONS 95 CITATIONS

SEE PROFILE
READS

208

Ana De Prada Pérez

National University of Ireland, Maynooth

16 PUBLICATIONS 62 CITATIONS

SEE PROFILE 


\section{Attitudes Toward Spanish and Code-Switching in Belize: Stigmatization and Innovation in the Spanish Classroom}

\section{Osmer Balam \& Ana de Prada Pérez}

To cite this article: Osmer Balam \& Ana de Prada Pérez (2017) Attitudes Toward Spanish and Code-Switching in Belize: Stigmatization and Innovation in the Spanish Classroom, Journal of Language, Identity \& Education, 16:1, 17-31, DOI: 10.1080/15348458.2016.1260455

To link to this article: http://dx.doi.org/10.1080/15348458.2016.1260455

曲 Published online: 01 Feb 2017.

Submit your article to this journal 지

a)

View related articles $\sqsubset$

View Crossmark data $\nearrow$ 


\title{
Attitudes Toward Spanish and Code-Switching in Belize: Stigmatization and Innovation in the Spanish Classroom
}

\author{
Osmer Balam ${ }^{a}$ and Ana de Prada Pérez \\ andiana University; b University of Florida
}

\begin{abstract}
Through the analysis of survey and interview data, we investigated the attitudes and perceptions of 32 multilingual teachers of Spanish in Belize, a code-switching (CS) context where Spanish is in intense contact with English and Belizean Kriol. More specifically, we examined teachers' and students' attitudes toward Spanish and CS and teachers' perceptions vis-à-vis students' attitudes toward Spanish instruction. The study revealed that whereas some teachers held negative views of Northern Belizean Spanish, they did not markedly perceive standard Spanish as "better" than the local variety of Belizean Spanish. The analysis also showed that most teachers had a positive predisposition to the use of CS as a pedagogical tool in their classrooms, a finding that suggests that ultra-normative attitudes toward Spanish varieties are not prevalent among these educators. In view of students' attitudes, teachers concurred that students had overwhelmingly negative attitudes toward standard Spanish, in line with previous findings. We argue that educational reforms and status-planning efforts are vital to destigmatize Spanish and to promote its maintenance alongside Belizean Kriol and English.
\end{abstract}

\section{KEYWORDS}

Belize; code-switching;

language attitudes;

sociolinguistics; Spanglish;

Spanish

\section{Introduction}

Language attitudes constitute a multidimensional construct that encompasses the thoughts and beliefs speakers have about language varieties, the feelings they hold toward these varieties, and the ways these beliefs and feelings are put into action in actual discourse (Baker, 1992). The investigation of teachers' language attitudes is crucial to our understanding of a bilingual community, as it provides a direct window into the degree of normativity present in the larger sociolinguistic and sociopolitical context. Furthermore, examining teachers' language attitudes and perceptions is vital, as their views and language practices have an indelible impact on the value that children and adolescents ascribe to their language varieties. We know that teachers play a crucial role not only in the maintenance of a language (MacGregor-Mendoza, 1998) but in the affirmation and co-construction of cultural identity (Palmer \& Martínez 2013; Palmer, Martínez, Mateus, \& Henderson, 2014; Weisman, 2001).

In previous research, it has been noted that teachers' attitudes toward students' home varieties can play a pivotal role in learners' performance in the language classroom (Bohn, 2003; Cummins, 2000; García-Nevarez, Stafford, \& Arias, 2005; González \& Darling-Hammond, 2000; Moodley, 2007; Palmer et al., 2014; Ramirez, Arce-Torres, \& Politzer, 1978). In Yiakoumetti and Esch's (2010) view, language teachers exercise a sociolinguistic responsibility, which encompasses not only instilling pride in learners' first dialect but ensuring that students embrace both the nonstandard home language and the standard variety as well. For Palmer and Martínez (2013), teachers are "arbiters" of

CONTACT Osmer Balam obalam@indiana.edu E Department of Spanish and Portuguese, Indiana University, 2137 Global and International Studies Building, Bloomington, IN 47405-1105. 
their classrooms' language policies and, as such, are in a special position to catalyze "educational opportunity for bilingual children" via the incorporation and skillful use of bilingual language practices as a means of promoting language development (p. 270).

In light of recent work which advocates for the skillful integration of bilingual students' hybrid language practices in the classroom (García, 2014; Martínez, 2010; Moodley, 2007; Palmer \& Martínez, 2013; Palmer et al., 2014), it is advantageous to further examine the attitudes that multilingual teachers themselves have toward CS, as they are the ones who ultimately legalize or alienate dynamic bilingualism in the classroom.

To date, research on teachers' attitudes toward Spanish or Spanish-English CS has primarily been conducted in the U.S. context. Boyd (2000), for example, examined bilingual teachers' attitudes toward the use of Spanish and the teaching of Spanish to Hispanic students in Louisiana. She found that most teachers had positive attitudes toward Spanish. In the survey, the majority of teachers concurred that teaching Spanish to Hispanic students contributes to their academic development and aids in the preservation of family heritage. MacGregor-Mendoza (1998) analyzed interview data from 77 bilingual teachers of Spanish from the Southern New Mexico and West Texas area. She also found that teachers had positive attitudes toward Spanish. Crucially, however, despite teachers' perception of Spanish as a symbol of pride, good fortune, friendship, and group membership, their generally positive attitudes did not align with their language use. An analysis of consultants' language use at home revealed that English was overwhelmingly used in the home domain for conversations about school, religion, and medical issues. Thus, MacGregor-Mendoza highlighted that even though these teachers were in a social position to foster the maintenance and use of Spanish, they were not doing so, even with their own children.

Nava (2009) found that teachers' language attitudes in South Texas varied according to the location of the school. Whereas teachers from schools in the South side of the region generally perceived CS as a limitation, teachers from North side schools did not. García-Nevarez et al. (2005), in their analysis of Arizona teachers' attitudes toward English language learners' native languages and their use in instruction, found that teachers' attitudes are also affected by other factors. The authors found there were significant differences in teacher attitudes based on type of certification, years of teaching, and ethnicity. Bilingual certified teachers were significantly more supportive of the use of Spanish for instructional purposes in the classroom than the mainstream and ESL-only certified teachers. Hispanic teachers also tended to have more positive attitudes toward students' native languages, in comparison to non-Hispanic teachers, and bilingual teachers had more positive attitudes than their monolingual counterparts.

In relation to Belize, no previous study has specifically examined teachers' attitudes toward Spanish or CS. In recent work, however, Balam (2013a) found that particularly postadolescent native speakers of Northern Belizean Spanish (NBS) had positive attitudes toward bilingual and trilingual CS and associated this language practice with their identity. In contrast, in the interviews, some adolescent speakers expressed very pejorative attitudes toward the use of standard Spanish (Balam, 2013a). In light of these recent findings, an important question raised is whether Belizean teachers of Spanish, who are native bilinguals or trilinguals, perceive CS positively as well. Also relevant are teachers' perceptions of students' attitudes, as students' reported attitudes may not necessarily reflect a general trend among Mestizo adolescents.

The present mixed-method study contributes to attitudinal research on Spanish-English bilingual communities by examining the understudied Spanish contact situation in Belize, specifically as it relates to teachers' attitudes toward Spanish and CS, and their perceptions regarding students' attitudes toward Spanish instruction.

\section{Spanish in Belize}

As in many other Latin American classroom contexts, the case of Belize involves the subtle interplay between a native contact variety of Spanish and the "classroom" standard variety. This is most 
evident in the districts of Corozal and Orange Walk, where NBS is natively spoken (Balam, 2013b, 2016b). Linguistically, what individualizes Belize in Central America is that although Spanish is the native language of the majority, English is the official language, and Belizean Kriol is the country's lingua franca (Balam, 2014). As a result of widespread societal multilingualism, the skillful alternation between languages is a common practice in this small but diverse Caribbean/Central American country (Balam, 2014, 2016b; Brockmann, 1979), particularly evinced among Mestizos in Northern Belize (Balam, 2013a, 2013b, 2016a).

A prominent aspect of Belizean society is the awareness and appreciation of ethnic and linguistic diversity. The coat of arms on the national flag depicts two men, a Mestizo woodcutter holding an axe and a Creole woodcutter holding a paddle, an iconic celebration of Belize's ethnic diversity. A testament to this appreciation for diversity is also evinced in the national language policy of Belize, which envisions first languages as bridges between the home language and the classroom language of instruction. The Government of Belize Language Policy (2000) highlights that "first languages are important vehicles for [children's] transition from home to school” (p. 183). The Government of Belize, in relation to Spanish,

recognizes Belize's geo-political situation and the status of Spanish as a major language of business and trade, and will support school and community efforts to enable students to acquire functional skills in the Spanish language by the end of primary school. (Chapter 1 , Section 6.5, p. 183)

Thus, first languages in Belize, including Spanish, are perceived as an integral component of classroom instruction. Given Belize's linguistic diversity, Spanish is taught either as a foreign language to non-Spanish speaking students or as a second dialect of Spanish to native speakers of NBS.

\section{The present study}

The purpose of the current study was twofold. We conducted a comparative analysis of teachers' and students' (adolescent and postadolescent) attitudes toward their Spanish varieties and CS (for a detailed analysis of the latter group, see Balam, 2013a). Secondly, we examined teachers' perceptions of students' attitudes toward standard Spanish instruction in the classroom. We acknowledge that participants' attitudes may differ from their actual practices; this is an issue we examine elsewhere (Balam, 2013a, 2016b).

\section{Participants}

A total of 32 Belize-born teachers, 15 males (ages 26 to 52) and 17 females (ages 23 to 49), who are currently full-time teachers of Spanish were recruited to participate in the study. The majority of teacher participants reported being exposed only to NBS at home before the age of eight, except for nine teachers who reported being simultaneously exposed to Spanish and other languages, including Yucatec Maya (two), English (four), and Belizean Kriol (three) before the age of eight. Ethnically, all 32 teachers self-identified as Mestizo (i.e., mixed Spanish and indigenous ancestry), with the exception of three teachers (i.e., one Maya, one "mixed," and one Mestizo Lebanese). Thus, students and teachers were largely similar in terms of their linguistic and ethnic background.

In terms of language use, on a scale of 1 to 7 (where 1-3 indicated rarely, 4-5 indicated sometimes, and 6-7 indicated very often), all participant groups, especially females, reported using Belizean Kriol the least $(M=3.6)$, a finding consonant with their self-reported proficiencies. As Table 1 shows, teachers reported feeling less proficient in Belizean Kriol and most proficient in Belizean Spanish and standard Spanish. Notably, female teachers reported engaging in CS more than their male counterparts.

The majority of teachers were originally from Northern Belize (21), whereas the remaining teachers were from Cayo (six) in Western Belize, Belize City (two), Stann Creek (one), and Toledo (two) in 
Table 1. Teachers' self-reported language use and language proficiencies on a 7-point scale.

\begin{tabular}{llccccc}
\hline $\begin{array}{l}\text { Background } \\
\text { information }\end{array}$ & $\begin{array}{c}\text { Participant } \\
\text { gender }\end{array}$ & Belizean Spanish & Standard Spanish & English & Kriol & Mixture \\
\hline Language use & Males & 5.8 & 5.2 & 5.8 & 4.2 & 4.3 \\
& Females & 5.7 & 5.0 & 5.9 & 3.6 & 5.2 \\
Self-rated proficiency & Males & 6.0 & 5.6 & 5.8 & 4.1 & 4.3 \\
& Females & 6.1 & 5.5 & 6.4 & 4.1 & 5.4 \\
\hline
\end{tabular}

Southern Belize, hence, providing us with insight into attitudes toward Spanish in different regions of Belize. Within the male group, participants' years of teaching Spanish in Belize ranged from 2 to 30 years $(M=8.9)$. In the female group, years of teaching Spanish ranged from 1 to 20 years $(M=7.9)$. This provided us with data from both novice and experienced teachers of Spanish. The survey data from teachers were compared to the data from adolescent $(n=14)$ and postadolescent $(n=28)$ students, whose native language was NBS (for a full description see Balam, 2013a).

\section{Data}

In line with previous work (Boyd, 2000; García-Nevarez et al., 2005; MacGregor-Mendoza, 1998), data for this mixed-method study are drawn from Likert scale questions, responses to open-ended questions, and interview data. A language background questionnaire was utilized to obtain information from the participants such as age, years of teaching Spanish in Belize, etc. For the purpose of comparative analyses, survey data were obtained via 15 statements on a 7 -point Likert scale $(1=$ completely disagree to $7=$ completely agree); the statements related to attitudes toward language use similar to those employed in Balam (2013a). These statements tapped into participants' attitudes toward (a) their local variety of Spanish in comparison to standard Spanish and to other varieties of Spanish, (b) the use of CS, and (c) the relationship between language use and identity. The teachers additionally responded to items related to their perception of student attitudes. These data were complemented with written responses to 14 openended questions, designed to elicit teachers' perceptions, attitudes, and insights regarding Spanish education in Belize. Qualitative data were further obtained via semi-structured interviews with 15 teachers, selected via purposeful sampling, who constituted a representative sample of the larger group. These individual or pair interviews were conducted to attain deeper insights into (a) the conative (Baker, 1992) aspect of teachers' attitudes (i.e., how their beliefs and feelings manifest themselves in discourse) and (b) teachers' experiences in relation to classroom instruction and professional development. It is important to note that the first author, a native of Northern Belize, who engaged in CS when it was appropriate according to community norms, collected the data. This ensured that consultants spoke freely and comfortably, hence, giving us insights into how teachers' attitudes and linguistic identities are projected in naturalistic discourse.

\section{Analysis}

For the quantitative data, teachers' ratings of the Likert scale statements were coded and submitted for within-group and across-group statistical analyses using SPSS. A comparative analysis was conducted between data from this study and the survey data reported in Balam (2013a). We decided to keep gender as a variable given that Balam (2013a) found some significant differences between male and female speakers vis-à-vis their predisposition to Spanish and CS. This yielded six groups for the quantitative analysis (male and female teachers, male and female adolescents, and male and female postadolescents). For clearer visual reference and comparison, we include data obtained from Balam (2013a) alongside survey data from the present study.

For the open-ended questions in the survey, written responses were extracted and coded for recurrent themes, issues, or topics across participants. Interview data, representing 12 hours of recorded speech, were also qualitatively analyzed for emergent themes across participants' oral 
responses. Following Boyd (2000), issues or themes (e.g., overt negative attitudes toward standard Spanish, the loss of ethnic identity, etc.) that emerged via specific examples or anecdotes at least five times among five different speakers served as the main basis for further elaboration vis-à-vis the quantitative data. Cases where certain issues or attitudes were found in one or two interviewees (e.g., negative attitudes toward native Spanish variety) were also included in order to provide contrasting views and perceptions. While we focus on the examination of the Likert scale statements, interview data and data from open-ended questions are employed to supplement this analysis and provide further insight into teachers' language attitudes and perceptions. The results are presented in the following section.

\section{Results}

We first present the results from the survey data comparing six groups of participants (male and female teachers, male and female adolescents, and male and female postadolescents), and we supplement this analysis with data from the survey's open-ended questions and the interviews. Three main topics were represented in the survey: attitudes toward their Spanish varieties, attitudes toward CS, and the relationship between language and identity. We discuss each in turn.

\section{Teachers' and students' attitudes toward Spanish}

Participants were asked to rate six statements that tapped into their attitudes toward their local Spanish variety. Comparing the attitudes reported by the six groups of speakers who took part in the survey revealed some common ideologies as well as some changing trends (see Table 2). For instance, although the survey data revealed descriptively that female teachers exhibited a more neutral attitude regarding the statement that NBS is not correct $(M=3.59)$ than the other groups (whose means ranged from 4.07 to 5.33), a one-way ANOVA revealed that there were no significant differences across the six groups, $F(5,73)=1.470, p=.21, \eta^{2}=.10$. All participant groups, especially the male and female teachers, also tended to disagree with the notion that they felt hesitant to speak Spanish in a Spanish-speaking country because of a fear that foreigners would make fun of their native Spanish accent. A one-way ANOVA confirmed that all groups disagree to the same degree, $F(5,73)=1.979, p=.09, \eta^{2}=.13$. Importantly, whereas both male and female teachers recognized the importance of standard Spanish, adolescent males do not do so to the same degree, $F(5$, 73) $=2.404, p=.046, \eta^{2}=.15$.

Lastly, when asked whether standard Spanish sounds better than their native variety, no significant group differences were obtained, $F(5,73)=.872, p=.51, \eta^{2}=.06$. Note that despite being teachers of Spanish, participants do not strongly agree with the idea that standard Spanish sounds better than NBS, suggestive of the fact that they do not necessarily perceive their nonstandard native variety as sounding "worse" than standard Spanish.

Table 2. Participants' attitudes toward their Spanish varieties.

\begin{tabular}{|c|c|c|c|c|c|c|c|c|c|c|c|c|}
\hline \multirow[b]{3}{*}{ Statement } & \multicolumn{4}{|c|}{ Teacher } & \multicolumn{4}{|c|}{ Adolescent } & \multicolumn{4}{|c|}{ Postadolescent } \\
\hline & \multicolumn{2}{|c|}{ Male } & \multicolumn{2}{|c|}{ Female } & \multicolumn{2}{|c|}{ Male } & \multicolumn{2}{|c|}{ Female } & \multicolumn{2}{|c|}{ Male } & \multicolumn{2}{|c|}{ Female } \\
\hline & $M$ & $S D$ & $M$ & $S D$ & $M$ & $S D$ & $M$ & $S D$ & $M$ & $S D$ & $M$ & $S D$ \\
\hline $1.1^{\mathrm{a}}$ & 4.07 & 1.75 & 3.59 & 2.17 & 4.87 & 1.31 & 4.41 & 1.83 & 4.37 & 1.18 & 5.33 & 1.21 \\
\hline $1.2^{\mathrm{b}}$ & 2.53 & 1.64 & 2.24 & 1.75 & 3.56 & 2.03 & 3.16 & 1.99 & 4.50 & 2.20 & 3.16 & 2.13 \\
\hline $1.3^{c}$ & 6.00 & 1.89 & 6.18 & 1.80 & 4.43 & 1.59 & 5.16 & 2.08 & 5.00 & 1.77 & 6.00 & 0.89 \\
\hline $1.6^{\mathrm{d}}$ & 4.67 & 2.23 & 5.00 & 1.95 & 4.75 & 1.52 & 3.75 & 1.81 & 5.25 & 1.98 & 4.83 & 1.47 \\
\hline
\end{tabular}

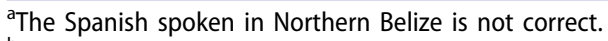

${ }^{b}$ Whenever I travel to a Spanish-speaking country such as Mexico, I feel hesitant to speak Spanish because I am afraid people will make fun of my accent.

It is important to speak standard Spanish.

${ }^{\mathrm{d} S t a n d a r d}$ Spanish sounds better than Northern Belizean Spanish. 
Overall, the interview data showed that most teachers had neutral attitudes toward their native variety. In other words, they did not describe NBS disparagingly. There were some references, however, in the oral interviews to Belizean Spanish as "kitchen Spanish" or español atravesado_ "mixed up Spanish," as it is often described in Belize. Notably, among some teachers, there was the perception that salient phonological aspects of NBS were errors that need remediation or correction. Two teachers explicitly described NBS as being "wrong." Consultant TE4, who highlighted her preference to speak only standard English or standard Spanish, made the following comment:

\section{Excerpt 1}

Me parece que el español beliceño no es bueno ... no se habla muy bien. No se pronuncia muy bien. Se pronuncia las erres como en inglés.

I think that Belizean Spanish is not good ... Spanish is not spoken well. It is not pronounced well. The rhotics are pronounced as in English. (TE4, female, 01:25-01:35)

The idea that monolingual varieties of Central American Spanish were more "correct" was also expressed by two other teachers. For instance, consultant TE14 remarked that Central American varieties are better than NBS, a perception that may be due, however, not only to her linguistic insecurity in standard Spanish but also to the fact that she is not a trained Spanish teacher. Although TE14 was proud of her ability to code switch, she repeatedly downplayed her "fluency" in standard Spanish. In an anecdote she shared about students who were native speakers of Central American Spanish varieties, she made the following comment:

\section{Excerpt 2}

Sus español es más mejor que el mío .... Hablan bastante em fluent ... porque vienen de El Salvador, Guatemala, $y$ otros países centroamericanos, y entonces hablan bastante el español, creo que hasta mejor que yo. No me gusta aceptarlo pero sí, son mejores.

Their Spanish is better than mine .... They are quite fluent ... because they come from El Salvador, Guatemala, and other Central American countries, and so they speak Spanish a lot, I think perhaps even better than me. I don't like to accept it, but yes, they are better. (TE14, female, 07:25-07:50)

In general, however, most teachers described Belizean Spanish as being simply "different."

In relation to participants' perception of students' attitudes, teachers concurred that students do not have a positive attitude toward standard Spanish. Female teachers disagreed with the statement, Students in Belize have a positive attitude toward learning and speaking standard Spanish $(M=2.71)$, whereas male teachers somewhat disagreed $(M=3.20)$. Among females, only two teachers somewhat agreed (i.e., rating of 5) that this is the case, whereas among male teachers there were two participants who agreed and two who strongly agreed with this statement. Note that teachers who perceived students' attitudes as positive taught Spanish either in Cayo (three) or in rural areas in Northern Belize (three), where in both cases, Spanish is predominantly spoken. Thus, more positive attitudes toward standard Spanish are found in rural areas. The interview data further supported this trend. Responses revealed that there is a clear line between teachers who teach Spanish in rural areas (four) versus those who teach Spanish in town or city schools (11). Whereas the former group reported generally positive attitudes toward Spanish in the classroom, the latter emphasized the challenges they face as a result of students' overtly negative attitude toward Spanish varieties.

In a close-ended question, teachers were further asked to indicate the variety or varieties students are positively or negatively predisposed to. As Figure 1 illustrates, more than $50 \%$ of teachers concurred that students have positive attitudes toward Belizean Kriol, followed by English and Belizean Kriol, whereas $84 \%$ of teachers felt that students had negative attitudes toward standard Spanish, Belizean Spanish, or both. No teacher indicated that students had a positive attitude toward standard Spanish.

In summary, teacher and student attitudes toward their local variety of Spanish were largely homogenous. All groups seem to indicate that their local variety is somewhat incorrect, but 


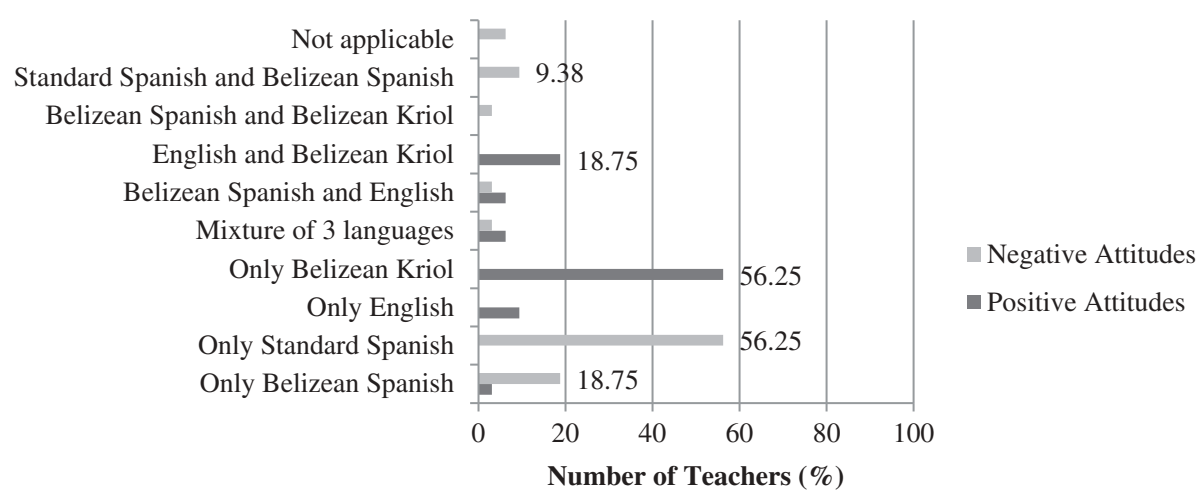

Figure 1. Teachers' perceptions of students' attitudes.

disparaging attitudes toward their native Spanish variety were not attested. The ratings are, for the most part, neutral. In the oral interviews, most teachers reported that Belizean Spanish was simply different. Unlike the results from the survey data on students' attitudes not differing significantly from teachers' attitudes, teachers perceive students' attitudes as different from their own-namely, in the importance attributed to standard Spanish. The next section further examines teacher attitudes in comparison to student attitudes with respect to the use of CS.

\section{Teachers' and students' attitudes toward CS}

In this section, we first examine the attitudes toward CS of teachers, adolescents and postadolescents in Northern Belize, as reported in three statements of the survey. Then, we further elaborate on these results by comparing them to oral interview responses by the teachers on their attitudes toward the use of CS in the classroom.

When asked if it bothers them when people mix their Spanish with English and sometimes even Belizean Kriol, teachers somewhat agreed with the statement, while adolescents' and postadolescents' ratings fall within the disagreement range (see Table 3). A one-way ANOVA, however, revealed no differences across the groups, $F(5,73)=1.876, p=.11, \eta^{2}=.12$. Thus, we can ascertain that none of the groups were negatively predisposed to the use of CS. Differences across groups did emerge for the statement "Being able to mix languages is an impressive skill that bilinguals have," $F(5,73)=8.616, p=.00, \eta^{2}=.39$. Numerically, the adolescent students are the only group to disagree with this statement. In particular, postadolescents and female teachers agreed with this statement significantly more than both adolescent groups $(p<.05)$. In addition, postadolescents also agreed more than male teachers $(p<.05)$; however, female teachers did not $(p>.05)$. Male teachers agreed significantly more than male adolescents $(p<.05)$, but not more than female adolescents $(p>.05)$.

Table 3. Participants' attitudes toward code-switching.

\begin{tabular}{|c|c|c|c|c|c|c|c|c|c|c|c|c|}
\hline \multirow[b]{3}{*}{ Statement } & \multicolumn{4}{|c|}{ Teacher } & \multicolumn{4}{|c|}{ Adolescent } & \multicolumn{4}{|c|}{ Postadolescent } \\
\hline & \multicolumn{2}{|c|}{ Male } & \multicolumn{2}{|c|}{ Female } & \multicolumn{2}{|c|}{ Male } & \multicolumn{2}{|c|}{ Female } & \multicolumn{2}{|c|}{ Male } & \multicolumn{2}{|c|}{ Female } \\
\hline & $M$ & $S D$ & $M$ & $S D$ & $M$ & $S D$ & $M$ & $S D$ & $M$ & $S D$ & $M$ & $S D$ \\
\hline $1.7^{\mathrm{a}}$ & 4.47 & 1.96 & 4.18 & 2.15 & 3.31 & 1.77 & 3.08 & 1.83 & 2.75 & 1.16 & 2.83 & 0.75 \\
\hline $1.10^{\mathrm{b}}$ & 4.00 & 2.33 & 5.00 & 2.11 & 2.50 & 1.15 & 3.00 & 0.95 & 5.75 & 1.28 & 5.83 & 0.40 \\
\hline $1.11^{\mathrm{c}}$ & 4.40 & 1.80 & 3.18 & 1.89 & 5.62 & 0.88 & 4.75 & 0.86 & 2.37 & 0.91 & 3.00 & 2.44 \\
\hline
\end{tabular}

a It bothers me when people mix their Spanish with English and sometimes even Belizean Kriol.

${ }^{\mathrm{b}}$ Being able to mix languages is an impressive skill that bilinguals have.

${ }^{c}$ If a person mixes two or more languages, this shows that he or she does not know any language well. 
Furthermore, adolescent speakers agreed that CS is reflective of not knowing any language well, whereas female teachers tended to disagree with this statement, which may be indicative of the female teachers' recognition of CS as a communicative strategy commonly used among speakers of Belizean Spanish, $F(5,73)=7.680, p=.00, \eta^{2}=.36$. For statement 1.11 , postadolescent speakers and female teachers disagreed more with this statement than both adolescent groups and male teachers $(p<.05)$. However, the difference in agreement between postadolescent females and male teachers did not reach significance. Note that only adolescents had ambivalent attitudes; whereas they do not perceive CS as a "skill," neither do they report feeling that it is reflective of not knowing any language well.

Teachers' patterns of language use were also revealing. During the interviews, 14 consultants fluctuated between monolingual Spanish and CS, whereas only TE4 spoke in a monolingual Spanish mode throughout the interview. Also noteworthy is that 10 out of 15 teachers did not describe CS disparagingly in the interviews, but instead, they emphasized that, particularly in areas where speakers are predominantly L1 Spanish speakers (i.e., rural areas in Northern Belize) or L1 Belizean Kriol speakers, first languages are used as instructional resources. TE8, for example, provided the following insight:

\section{Excerpt 3}

Hay maestros que enseñan, por ejemplo, estudios sociales y otras materias, e incluso inglés ... que utilizan el español en la clase porque eso es lo que los estudiantes entienden más.

There are teachers that teach, for example, social studies and other subjects, including English ... who use Spanish in the classroom because that is what the students understand more. (TE8, female, 05:53-06:22)

This reveals, therefore, that the use of first languages alongside English is sometimes employed in the Belizean classroom, a practice that seems to have been present since colonial times (see Hagerty, 1979; Koenig, 1975). A salient trend in the data from the open-ended questions was that teachers who had lived abroad were negatively predisposed to the use of first languages or CS in the classroom. For example, when asked about her thoughts on language mixing ${ }^{1}$ in the classroom, T6, who had lived in Guatemala for 2 years, wrote, "I think it's sad. We can do much better." Consultant T11, who had lived in Mexico for 2 years, commented, "Language mixing should not be allowed as it affects the learning of standard Spanish. It might promote local customs but hurt the students' ability to communicate at home and abroad." With the exception of teachers who had lived abroad either in Mexico or Guatemala and who felt that language alternation should not be allowed in class, $63 \%$ of consultants either had neutral attitudes (i.e., would tolerate but not encourage it) toward Belizean Spanish and CS or expressed that language mixing can serve as an instructional resource in the Spanish classroom. Below are some of the responses teachers wrote to the openended question, "What do you think about language mixing during Spanish class?"

It is great as this is the beginning of their language development. [T3, female, 42]

It's good for the person not used to speaking Spanish to be able to communicate and understand the lesson.

[T7, male, 43]

Language mixing can serve as a means to an end...the end being learning Spanish.

[T18, female, 53]

I think that it can be used as a tool for those who are starting to speak Spanish as they learn new words. It's fun. [T29, male, 32]

It promotes learning. [T30, male, 41]

I think it is good up to a certain extent. Language mixing I find is excellent especially when trying to explain concepts. [T1, female, 38]

Overall, the data presented in this section indicate that both students and teachers exhibit mainly positive attitudes toward CS and, although not in complete agreement, teachers tend to see CS as a positive resource in their classrooms. In the following section, we switch our attention to these speakers' reported relationship between language and identity. 


\section{Teachers' and students' reported relationship between language and identity}

Three statements in the survey tapped on the relationship between language use and identity. We first compare the six groups regarding their responses to the survey and complement these responses with teachers' responses to the open-ended written questions and oral interview.

Data on participants' perceptions of their language varieties in relation to their identities were also revealing (see Table 4). A one-way ANOVA revealed no group differences, $F(5,73)=1.097, p=.37$, $\eta^{2}=.07$. All participant groups, especially female teachers agreed that they are proud of their unique accent, in line with female teachers' disagreement with statement 1.6 that standard Spanish sounds better than NBS.

Noteworthy is that teachers gave neutral ratings to the notion that language mixing reflects who they are, whereas the students tended to agree that CS does reflect who they are. In this case, group differences were attested, $F(5,73)=2.944, p=.02, \eta^{2}=.18$. Adolescent and postadolescent groups agreed with this statement significantly more than male teachers $(p<.05)$. In the case of postadolescent males, they also agreed significantly more than female teachers $(p<.05)$. This is unsurprising given that teachers, especially males, reported infrequent use of CS in comparison to their native Spanish variety and English (again, see Table 1).

As indicated above, Belizean participants acknowledged the importance of standard Spanish but not to the detriment of their local variety. Additionally, CS, although not by all groups, is considered an indication of an impressive skill. In particular, female teachers showed a tendency to be more positively predisposed to CS than their male counterparts.

Thus, despite not associating CS with their identity, the majority of teachers revealed a positive predisposition to the use of first languages and CS in the classroom, a fact that differs from other contexts, such as some communities in the U.S. Spanish-English context, where a prevailing ideology is that "Spanish is the root cause of underachievement of students who are native Spanish speakers" (Escamilla, 2006, p. 2329).

A recurrent theme in the interview data was teachers' realization that young Mestizos in Northern Belize are increasingly not only shifting away from Spanish, but also losing sight of the ethnolinguistic vitality of their first language. Consultant TE6, who has been teaching Spanish in Northern Belize for 18 years, made the following comment:

\section{Excerpt 4}

Antes los estudiantes sí lo aceptaban mucho más, el español, que ahora. Ahora yo diría que ... hasta nos sorprende que los de la aldea no todos quieren hablar el español ... y muchos creen que no es tan importante, que no les va a ayudar...

Before the students accepted it more-Spanish-than now. Now I would say that ... it even surprises us that even students from the villages don't want to speak Spanish ... and many students believe that it is not too important, that Spanish won't help them. (TE6, female, 01:40-2:02)

TE6 further explained that students in general do not perceive Spanish as either important or useful to them given that Belize is officially an English-speaking country. Eight consultants

Table 4. Participants' attitudes toward their varieties and identities.

\begin{tabular}{|c|c|c|c|c|c|c|c|c|c|c|c|c|}
\hline \multirow[b]{3}{*}{ Statement } & \multicolumn{4}{|c|}{ Teacher } & \multicolumn{4}{|c|}{ Adolescent } & \multicolumn{4}{|c|}{ Postadolescent } \\
\hline & \multicolumn{2}{|c|}{ Male } & \multicolumn{2}{|c|}{ Female } & \multicolumn{2}{|c|}{ Male } & \multicolumn{2}{|c|}{ Female } & \multicolumn{2}{|c|}{ Male } & \multicolumn{2}{|c|}{ Female } \\
\hline & $M$ & $S D$ & $M$ & $S D$ & $M$ & $S D$ & $M$ & $S D$ & $M$ & $S D$ & $M$ & $S D$ \\
\hline $1.12^{\mathrm{a}}$ & 5.73 & 1.71 & 5.41 & 1.18 & 4.75 & 1.84 & 4.42 & 2.10 & 5.38 & 1.50 & 4.67 & 1.75 \\
\hline $1.13^{\mathrm{b}}$ & 5.87 & 1.30 & 6.12 & 1.60 & 5.44 & 1.15 & 5.83 & 1.19 & 5.63 & 1.40 & 5.83 & 0.40 \\
\hline $1.15^{\mathrm{c}}$ & 3.93 & 1.88 & 4.41 & 2.35 & 5.50 & 1.46 & 5.58 & 1.44 & 6.13 & 0.64 & 5.67 & 0.81 \\
\hline
\end{tabular}

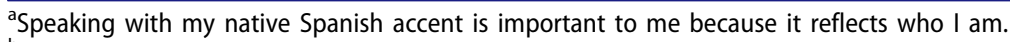

$\mathrm{b}_{\mathrm{I}}$ am very proud of my unique Spanish accent.

'The mixture of English, Spanish (and Belizean Kriol) reflects who I am. 
mentioned that even some students who are from villages now refuse or deny speaking Spanish. These students try to completely dissociate themselves from Spanish not only linguistically but also culturally. The loss of culture among young Mestizos was highlighted by several teachers. TE15 shared the following example:

\section{Excerpt 5}

Tratamos una vez de tener un día de la cultura aqui y fue un fallo total ... porque imagínate ... tienes a niños Mestizos, tienes algunos que son más Mayas que Mestizos queriendo vestirse de Criollos.

We once tried to have Culture Day here and it was a complete failure ... because imagine ... you have Mestizo children, you have some who are more Maya than Mestizo trying to dress up like Creoles. (TE15, male, 20:17-20:48)

This is a rather noteworthy phenomenon as we can see that sometimes a change in the status of a previously stigmatized language (i.e., Belizean Kriol) can result not only in the subsequent stigmatization and displacement of another language but changes in the younger generation's sense of ethnic identity. Several consultants shared anecdotes in which young Mestizos proudly claimed to be "Creoles" despite their obvious Maya or Mestizo heritage. This was most candidly characterized in TE3's experience with some of her students. She commented:

\section{Excerpt 6}

Yo siempre les digo. ¡Por favor! ¡Véanse ustedes! Son indios igual a mí ... somos indios ... hay que hablar nuestra lengua ... y ellos dicen "No Ms. Mi dah noh laik yu! Mi dah Creole." Y en nada. Les preguntas, quienes son tus padres, tus abuelos, tus apellidos, y todo es descendencia Mestiza [pero] simplemente no lo aceptan.

I always tell them. Please! Look at yourselves! You are Mestizos just like me ... we are Mestizos ... we have to speak our language ... and they say, "No Ms. We are not like you! I am a Creole." And they have no Creole background. You ask them about their parents, their grandparents, their surnames, and everything is Mestizo descent, [but] they simply don't accept it. [TE3, female, 07:27-07:56]

These observations support Balam's (2013a) contention that in contrast to previous decades when ethnic identity determined language choice in Northern Belize (Koenig, 1975), some younger Mestizos in urban areas are now embracing a strong pan-Afro Belizean identity, one which is displacing their linguistic and ethnic identities. This strong pan-Afro Belizean identity among adolescent Mestizos in urban schools often manifests itself in overtly negative attitudes toward Spanish. Teachers highlighted that native Belizean Mestizos are often ostracized or mocked by their peers if they try to speak standard Spanish, resulting in students' hesitation to use Spanish in and out of the classroom. This pejorative attitude was previously attested only toward standard English. In her sociolinguistic analysis of language choice and code-switching in Corozal, Northern Belize, Koenig (1975) reported that "students frown on attempts to use standard English ... [and] several students at the secondary level reported that, in inter-ethnic situations, other students laugh at them if they try to speak English instead of Creole" (p. 111). Koenig further comments that students exerted peer pressure in order to achieve linguistic conformity. We see that these negative attitudes are being directed now particularly toward standard Spanish.

Also noteworthy is the fact that several teachers shared anecdotes suggesting that adolescent monolingual Spanish speakers who immigrate to Belize can only integrate into the adolescent culture if they start speaking Belizean Kriol and overtly display a negative attitude toward Spanish. Consultant TE15 provided an insight into this phenomenon:

\section{Excerpt 7}

Vienen personas de El Salvador, por ejemplo, vienen y estudian aquí y hasta esas personas... Ya luego ya no los escuchas hablando el español, ya los escuchas hablando criollo .... Tenemos como cuatro aquí ahora y en el lapso de un año me he dado cuenta cómo cambian y hasta la actitud, la mentalidad hacia el español cambia. 
Persons from El Salvador come here, for example, and they study here, and even those individuals ... afterwards you no longer hear them speaking Spanish. You hear them speaking Creole .... We have about four students here now, and in the lapse of 1 year, I have noticed how they change and even their attitude, the mentality toward Spanish changes as well. (TE15, male, 24:59-25:26)

This is a kind of linguistic resistance that further complicates teachers' efforts to teach standard Spanish at the high school level. Another pattern that was salient, which was highlighted by six teachers, was that students insist on using nonstandard rather than standard forms in the classroom. Some students also insist that their native variety's variant is the "correct" form that ought to be used. In particular, consultants pointed out the case of rhotics. In NBS, a retroflex approximant $/ \mathrm{d} /$ is used in place of the canonical apico-alveolar trill /r/. TE3 shared several anecdotes in which her students insisted that the "correct" way to pronounce perro "dog" is with the retroflex variant rather than with the canonical trill. They also insist on using nonstandard verb forms such as loanblends (e.g., trayar "to try"). Another noteworthy aspect of their linguistic behavior is that both in and outside of class, they frequently experiment with the Spanish language, purposefully changing and breaking its rules, as in $E l$ burzer ya ringió "The buzzer has rung," where an epenthetic rhotic is inserted for a humor effect and the loanblend ringió "has rung" is used in place of the monolingual Spanish verb equivalent.

In this regard, we can see that Mestizo Belizean students' attitudes toward Spanish are not only varied but multifaceted, and this may account for the ambivalence we found. Whereas in rural schools, attitudes toward Spanish are largely positive, in urban schools there is a starkly different dynamic. Students' markedly negative attitudes toward standard Spanish in town and city schools can take the form of derision, base humor, or the rejection of standard Spanish forms. At the same time, we can see that particularly students' pervasive use of nonstandard forms is a trend that may be a living reflection of the speech community's linguistic norms, where bi/multilingual language practices constitute a normal dimension of everyday life (Balam, 2016b).

The data presented in this section revealed an interesting interplay between language and identity as well as between adolescent and postadolescent attitudes in comparison with their attitudes as perceived by their teachers. In the following section, we elaborate on our results.

\section{Discussion and conclusion}

We set out to examine (a) teachers' and students' language attitudes and (b) teachers' perceptions regarding their students' attitudes toward Spanish instruction. The survey data revealed that female teachers showed a more positive predisposition toward standard Spanish, whereas male teachers showed more neutral attitudes. At the same time, however, female teachers generally disagreed that NBS is "not correct." They were also more positively predisposed to CS than their male counterparts, a pattern consonant with previous work that shows females are generally more positively predisposed toward CS (Dewaele \& Wei, 2014). The interviews provided a more multidimensional insight into teachers' attitudes toward Spanish and CS. It also portrayed a vivid picture of their experiences and challenges as teachers of Spanish in a community where Spanish is increasingly becoming stigmatized, even among young immigrants who are native speakers of monolingual varieties of Central American Spanish.

Overall, results from the present study suggest that Belizean multilingual teachers of Spanish do not have ultra-normative attitudes toward Spanish varieties. Contrary to MacIntosh and Ornstein's (1974) argument that hypercorrect and ultra-normative attitudes toward nonstandard language varieties are especially pronounced among Hispanic teachers themselves (i.e., teachers who are native speakers of a stigmatized variety), we can see that the bilingual and multilingual teachers from the present study generally embrace their native bilingual discourse practices. Ultra-normative attitudes toward varieties of Spanish were only found among a few teachers, particularly among those who had lived or studied abroad. It may be that the stigmatization they encountered abroad as a result of their native Spanish variety resulted in their more marked negative attitudes toward NBS upon their return to Belize. 
It was clear, however, that Spanish teachers' attitudes, ideologies, and linguistic behaviors generally align with the linguistic norms attested in their community, where there are low levels of linguistic prescriptivism and where it is standard varieties that are marked (Balam, 2013a). It also aligns with the country's national language policy. Participants' linguistic behaviors were not indicative of ultra-normative attitudes toward language varieties. The qualitative analysis of teachers' written responses showed that $63 \%$ of Spanish teachers had either neutral or positive attitudes toward language mixing in the classroom. One can surmise that among Belizean native Spanish-speaking teachers of other academic subjects, in which language learning is not the central focus, there is even a more positive predisposition toward the use of CS or Belizean Kriol in the classroom. Particularly, the survey data suggest female teachers may more frequently employ bilingual language practices in the Belizean classroom. This points to the fundamental role female teachers, across academic levels, may play in the transmission of positive attitudes toward CS practices to younger generations, an issue we will more closely examine in future research.

In contrast to other studies in which CS is largely perceived to be in direct opposition to normative perceptions of what a "good language" is (Nava, 2009; Ramirez \& Milk, 1986), the current study suggests that many educators in the Belizean context capitalize on language mixing. Many teachers, instead of marginalizing CS from the Spanish classroom, employ it as a strategy and as a pedagogical tool to facilitate language learning, thus, aligning their classroom speech practices with those that are prevalent and unmarked in the community. This finding is in line with work that advocates for the value and use of CS as an instructional resource that can be exploited in the classroom (Cook, 2001; Gutiérrez, Baquedano-López, \& Tejeda, 1999; Macaro, 2005; Martínez, 2009, 2010; Moodley, 2007; Moore, 2002; Palmer \& Martínez, 2013; Palmer et al., 2014; Villa, 1996).

We assert that the acceptance of CS as a legitimate communicative or learning strategy in classrooms, accomplished overtly (i.e., by participating in it) or covertly (i.e., allowing students to engage in it), contributes to the ethnolinguistic vitality of this behavior beyond the confines of the language classroom, as it builds a valuable bridge, a sense of continuity, between home and school. The fact that teachers of Spanish do not exhibit strong pejorative attitudes toward CS helps to partly explain why CS has thrived in Belize. In previous work, scholars argue that it is precisely in academia that linguistic purism, hegemonic monolingual views, and ultra-normative attitudes toward language varieties are propagated (Escamilla, 2006; Felix, 2009; Suárez, 2002; Valdés, González, López García, \& Patricio, 2003; Villa, 2002). Notably, in some contexts, teachers deliberately choose not to engage in CS. For example, Collins (2003) found that in interviews, teachers who were native speakers of Mam in Guatemala deliberately avoided switching to Spanish. Only lesser educated speakers engaged in CS. In contrast, research on the cross-generational use of mixed determiner phrases (e.g., un house "una casa") and bilingual light verb constructions (e.g., hizo buy un gift "she bought a gift") shows that bilinguals and trilinguals who are professionally trained teachers in Northern Belize evince an impressive use of intrasentential CS when speaking about a variety of topics (Balam, 2016b). Thus, these data support the idea that among Mestizos who speak Belizean Spanish natively, even educated individuals do not have ultra-normative attitudes toward CS and Belizean Kriol.

In relation to students' attitudes toward Spanish, however, we see different phenomena. Standard Spanish is the variety that is stigmatized the most, especially among adolescent males who display overt resistance toward the use of standard Spanish. This resistance manifests itself in the rejection and the playful derision of standard forms, such as the apico-alveolar trill and the persistent use of regional, nonstandard forms such as the retroflex approximant, loanblends (e.g., ringyar "to ring"), and bilingual compound verbs (e.g., hacer print "to print"), distinctive features characteristic of NBS (Balam, 2014, 2016b). The negative attitudes toward standard Spanish, thus, result in adolescent speakers' avoidance of standard Spanish. This occurs even among immigrant adolescents from officially Spanish-speaking Central American countries who adapt themselves to the host culture by adopting either CS or Belizean Kriol.

Thus, in contexts like Belize, where multilingualism is the norm and CS is sanctioned as legitimate at a societal level, the classroom can sometimes be a social space where there is active resistance against canonical phonological and grammatical forms and where existing and emerging 
innovations are espoused. In these contexts, our primary challenge is to destigmatize the standard variety in an effort to motivate students to want to embrace it as a part of their multidimensional linguistic repertoire.

Findings from this study suggest that in the case of Belize, linguistic hegemony is associated with Belizean Kriol rather than English or other monolingual varieties of Central American Spanish. More research needs to be carried out, however, to elucidate this issue. In recent decades, Belizean Kriol has increasingly gained acceptability and use in public and private domains, whereas Spanish varieties are increasingly becoming stigmatized. Notably, however, CS is still valued among the younger generation, perhaps as a result of its neutrality. Romaine (1995) aptly points out that CS allows speakers "to tread a more neutral path between opposing identities symbolized in two [or more] languages" (p. 301). CS allows speakers to use their native Spanish variety, while also allowing the skillful incorporation of English and Belizean Kriol.

In relation to the present findings, it must be underscored that some teachers did have negative attitudes toward NBS, particularly its phonology and syntax. In the interviews, a recurrent example discussed was the case of the retroflex approximant rhotic, a salient sound in NBS, which many teachers perceived as "incorrect." Teachers seemed unaware that the retroflex approximant is not exclusive to Belize. In fact, this is just another rhotic variant found in several other contact Spanish varieties, both in Latin America and the United States (for further discussion on rhotics in Belize see Balam, 2013b). It is imperative, therefore, that Belizean teachers of Spanish become better acquainted with dialectal variation in monolingual and contact varieties of Spanish. Teacher-training efforts must continually emphasize the importance of linguistic variation and additive bidialectalism, and avenues need to be explored through which Belizean Spanish and standard Spanish grammatical systems are presented to students as complementary rather than conflictive.

A salient view among teachers was that more government and school initiatives have to be taken to ensure that the maintenance and use of Spanish is promoted not only at the high school level but also at the elementary and kindergarten levels. While teachers applauded the government's launching of the Spanish education program to train teachers of Spanish at the University of Belize in 2010, they reported feeling there was a lack of continued support in terms of professional development programs for them. They expressed their belief that school administrators also need to play a more active role in promoting the importance of Spanish in schools. In a few cases, former high school students now pursuing higher education in Mexico were invited to give talks to current high school students about their experiences. More such forums across Belize are necessary for students to recognize the value of Spanish in academic and professional spheres.

While Belizean Kriol continues to gain prestige in Belize, Spanish cannot be undermined, especially given the fact that Belize is after all a Central American country that stands to gain tremendously from closer ties with Spanish-speaking Latin America in the areas of education, business, and agriculture. Today, many Belizean students pursue studies in agriculture, medicine, or other fields in Cuba, Mexico and Central America. A recurrent theme among teachers of Northern Belize was that the Caribbean Examinations Council's (CXC) secondary school Spanish exam was not appropriate for native Spanish-speaking students given that the exam is particularly tailored for students in the Anglophone Caribbean who do not have a background in Spanish. Mestizo Belizean students already have a native Spanish variety, which they need to build on in an effort to learn an academic variety of Spanish.

Note that most high schools and junior colleges in Belize follow the syllabus for Spanish provided by the CXC, a regional examining body established in 1972 that regulates examinations and certifications in 16 Commonwealth Caribbean countries. As teachers aptly pointed out, however, this syllabus specifically caters to Spanish as a second language students and not to students who are already exposed to Spanish at home. To date, there is no standardized national syllabus, with specified goals, objectives, and learning outcomes for high schools. Thus, although the importance of Spanish is recognized in the national language policy, in practice Belize has lagged behind in terms of institutionalized efforts gearing toward bolstering the learning of Spanish in schools. 
In order for Belizean high school students to be able to capitalize on Latin American scholarship opportunities to pursue careers that will contribute to Belize's development, it is of critical importance that they receive a solid foundation in academic Spanish, which will facilitate their transition to universities where standard Spanish is the language of instruction. For this to be accomplished, teachers will first need to be equipped and trained with the necessarily skills to teach standard Spanish as an additional variety that will enrich students' linguistic repertoire. This will also require the development of a national syllabus, locally tailored for the varied needs of students in Belizean classrooms.

Although the current study provides valuable insights into Belizean teachers' and students' attitudes toward Spanish varieties and CS in the classroom, more research is needed to examine a larger sample size and elaborate on the attitudinal differences between speakers from rural and urban areas and between speakers from different ethnic backgrounds. Furthermore, an in-depth investigation of student-teacher interactions in the classroom is vital to further analyze and understand how "students' hybrid language practices are incorporated, privileged, and leveraged to promote learning" (Palmer \& Martínez, 2013, p. 289) in Belizean multilingual classrooms.

\section{Note}

1. We use the terms language mixing and code-switching interchangeably. Note that students and the majority of teachers were not acquainted with sociolinguistic terminology; thus, for them, language mixing is a more appropriate term that describes the alternation of languages in naturalistic discourse.

\section{References}

Baker, C. (1992). Attitudes and language. Philadelphia, PA: Multilingual Matters.

Balam, O. (2013a). Overt language attitudes and linguistic identities among multilingual speakers in northern Belize. Studies in Hispanic and Lusophone Linguistics, 6, 247-277. doi:10.1515/shll-2013-1150

Balam, O. (2013b). Variable neutralization of the intervocalic rhotic contrast in northern Belizean Spanish. Borealis-An International Journal of Hispanic Linguistics, 2(2), 285-315. doi:10.7557/1.2.2.2601

Balam, O. (2014). Notes on the history and morphosyntactic characteristics of Spanish in northern Belize. Kansas Working Papers in Linguistics, 35, 79-94. doi:10.17161/KWPL.1808.15953

Balam, O. (2016a). Semantic categories and gender assignment in contact Spanish: Type of code-switching and its relevance to linguistic outcomes. Journal of Language Contact, 9(3), 405-435. doi:10.1163/19552629-00903001

Balam, O. (2016b). Language use, language change, and innovation in northern Belize contact Spanish (Unpublished doctoral dissertation). University of Florida, Gainesville, FL.

Bohn, P. A. (2003). Familiar voices: Using Ebonics communication techniques in the primary classroom. Urban Education, 38, 688-707. doi:10.1177/0042085903257315

Boyd, R. (2000, December). Attitudes of teachers of Spanish as a foreign language towards teaching Spanish to Hispanic students. Paper presented at the Annual Meeting of the Modern Language Association, Washington, DC. Retrieved November 15, 2014 from http://files.eric.ed.gov/fulltext/ED447719.pdf.

Brockmann, T. (1979). Language, communication and ethnicity in British Honduras. In W. F. Mackey \& J. Ornstein (Eds.), Sociolinguistic studies in language contact: Methods and cases (pp. 161-180). The Hague, NL: Mouton.

Collins, W. M. (2003). Code-switching behavior as a strategy for Maya-Mam linguistic revitalization. Ohio State University Working Papers in Linguistics, 57, 1-39.

Cook, V. (2001). Using the first language in the classroom. Canadian Modern Language Review, 57, $402-423$. doi: $10.3138 / \mathrm{cmlr} .57 .3 .402$

Cummins, J. (2000). Negotiating intercultural identities in the multicultural classroom. CATESOL Journal, 12(1), $163-178$.

Dewaele, J., \& Wei, L. (2014). Attitudes towards code-switching among adult mono- and multilingual language users. Journal of Multilingual and Multicultural Development, 35, 235-251. doi:10.1080/01434632.2013.859687

Escamilla, K. (2006). Semilingualism applied to the literacy behaviors of Spanish-speaking emerging bilinguals: Bi-illiteracy or emerging biliteracy? Teachers College Record, 108, 2329-2353. doi:10.1111/j.1467-9620.2006.00784.x

Felix, A. (2009). The adult heritage Spanish speaker in the foreign language classroom: A phenomenography. International Journal of Qualitative Studies in Education, 22, 145-162. doi:10.1080/09518390802703414

García, O. (2014). U.S. Spanish and education: Global and local intersections. Review of Research in Education, 38, 58-80. doi:10.3102/0091732X13506542 
García-Nevarez, A., Stafford, M., \& Arias, B. (2005). Arizona elementary teachers' attitudes toward English language learners' and the use of Spanish in classroom instruction. Bilingual Research Journal, 29, 295-317. doi:10.1080/ 15235882.2005.10162837

González, J. M., \& Darling-Hammond, L. (2000). New concepts and new challenges: Professional development for teachers of immigrant youth. Washington, DC: Center for Applied Linguistics.

Government of Belize Language Policy. (2000). Handbook of policies and procedures for school services. Belmopan, Belize: Ministry of Education, Youth and Sports.

Gutiérrez, K. D., Baquedano-López, P., \& Tejeda, C. (1999). Rethinking diversity: Hybridity and hybrid language practices in the third space. Mind, Culture, and Activity, 6, 286-303. doi:10.1080/10749039909524733

Hagerty, T. W. (1979). Phonological analysis of the Spanish of Belize (Unpublished doctoral dissertation). University of California, Los Angeles, CA.

Koenig, E. L. (1975). Ethnicity and language in Corozal District, Belize: An analysis of code-switching (Unpublished doctoral dissertation). University of Texas, Austin, TX.

Macaro, E. (2005). Codeswitching in the L2 classroom: A communication and learning strategy. In E. Llurda (Ed.), Non-native language teachers: Perceptions, challenges, and contributions to the profession (pp. 63-84). Boston, MA: Springer.

MacGregor-Mendoza, P. (1998). Language and the bilingual teacher: Use, attitudes, roles. Southwest Journal of Linguistics, 17(2), 83-99.

MacIntosh, R., \& Ornstein, J. (1974). A brief sampling of West Texas teacher attitudes toward southwest Spanish and English language varieties. Hispania, 57, 920-926. doi:10.2307/339767

Martínez, R. A. (2009). Spanglish is spoken here: Making sense of Spanish-English codeswitching and language ideologies in a sixth-grade English language arts classroom (Unpublished doctoral dissertation). University of California, Los Angeles, CA.

Martínez, R. A. (2010). Spanglish as literacy tool: Toward an understanding of the potential role of Spanish-English code-switching in the development of academic literacy. Research in the Teaching of English, 45, 124-149.

Moodley, V. (2007). Code-switching in the multilingual English first language classroom. International Journal of Bilingual Education and Bilingualism, 10, 707-722. doi:10.2167/beb403.0

Moore, D. (2002). Code-switching and learning in the classroom. International Journal of Bilingual Education and Bilingualism, 5, 279-293. doi:10.1080/13670050208667762

Nava, G. N. (2009). Elementary teachers' attitudes and beliefs towards their students' use of code-switching in south Texas. Lenguaje, 37(1), 135-158.

Palmer, D., \& Martínez, R. A. (2013). Teacher agency in bilingual spaces: A fresh look at preparing teachers to educate Latino/a bilingual children. Review of Research in Education, 37, 269-297. doi:10.3102/0091732X12463556

Palmer, D. K., Martínez, R. A., Mateus, S. G., \& Henderson, K. (2014). Reframing the debate on language separation: Toward a vision for translanguaging pedagogies in the dual language classroom. Modern Language Journal, 98, 757-772. doi:10.1017/S0267190514000233

Ramirez, A. G., Arce-Torres, E., \& Politzer, R. (1978). Language attitudes and the achievement of bilingual pupils in English language arts. Bilingual Review, 5, 190-206.

Ramirez, A. G., \& Milk, R. D. (1986). Notions of grammaticality among teachers of bilingual pupils. TESOL Quarterly, 20, 495-513. doi:10.2307/3586296

Romaine, S. (1995). Bilingualism. Oxford, UK: Blackwell.

Suárez, D. (2002). The paradox of linguistic hegemony and the maintenance of Spanish as a heritage language in the United States. Journal of Multilingual and Multicultural Development, 23, 512-530. doi:10.1080/01434630208666483

Valdés, G., González, S. V., López García, D., \& Patricio, M. (2003). Language ideology: The case of Spanish in departments of foreign languages. Anthropology and Education Quarterly, 34, 3-26. doi:10.1525/aeq.2003.34.1.3

Villa, D. (1996). Choosing a "standard variety of Spanish for the instruction of native Spanish speakers in the U.S. Foreign Language Annals, 29, 191-200. doi:10.1111/j.1944-9720.1996.tb02326.x

Villa, D. (2002). The sanitizing of U.S. Spanish in academia. Foreign Language Annals, 35, 222-230. doi:10.1111/j.19449720.2002.tb03156.x

Weisman, F. M. (2001). Bicultural identity and language attitude perspectives of four Latina teachers. Urban Education, 36, 203-225. doi:10.1177/0042085901362004

Yiakoumetti, A., \& Esch, E. (2010). Educational complexities inherent in bidialectal communities and the potential contribution of the common European framework of reference to second-dialect development. In B. O’Rourke \& L. Carson (Eds.), Language learner autonomy: Policy, curriculum, classroom. Contemporary studies in descriptive linguistics (pp. 291-312). Oxford, UK: Peter Lang. 